David Murray and Steven Bell

\title{
Exploring the faculty blogoverse Where to start and what's in it for academic librarians
}

$\mathbf{T}_{\mathrm{n}}^{\mathrm{h}}$ he reading and writing of Weblogs is now mainstream behavior in academic librarianship. Librarian blog activity manifests itself in any of these ways: contributing to one's own institutional library blog, maintaining a personal librarian blog, reading blogs about librarianship or peripheral fields. Subscribing to librarian blogs is a vital component of a strategic process for keeping up. One can choose from a variety of blogs for obtaining news and information (Peter Scott's Library Blog, LISNews, Kept-Up Academic Librarian), keeping alert to recent technology developments (ALA Techsource Blog, Infodoodads, Phil Bradley's $B \log$ ), or staying abreast with the latest commentary on the profession (ACRLog, Walt at Random, The Ubiquitous Librarian).

A successful strategic keeping-up regimen requires more than a steady diet of content from within one's own profession. To invigorate inspiration and ideation, it's of great value to go beyond the borders of one's own professional literature. That is why every academic librarian's keeping-up strategy should include, for example, feeds from standard higher education sources (The Chronicle's Daily News, Inside Higher Ed, Wired Campus $B l o g$, and other academia-related blogs from organizations, such as EDUCAUSE). This article seeks to take academic librarians into a lesser explored territory, where vast potential lies for those willing to explore. Too few of us have yet to discover the value of faculty blogs.

In this article we will identify resources for locating faculty blogs, identify some wellregarded faculty blogs worthy of review, and discuss how faculty blogs can benefit academic librarians and why we should be reading them as part of our regular keeping up routine. Our goal is to encourage our academic librarian colleagues to add more faculty blogs to their regular regimen of blog reading.

\section{Venturing into the faculty blogoverse}

Librarian blogs, even those authored by academic librarians, rarely, if ever, point their readers to faculty blog posts. A good first step in exploring the faculty blogoverse is to read two seminal readings on the world of faculty blogging. The first appeared June 6, 2003, authored by David Glenn in the Chronicle of Higher Education. Glenn's article on "Scholars who blog" is the first serious look at faculty bloggers, and seeks to enlighten us on why faculty blog at all, since blogging is hardly a scholarly form of publication. Beyond just offering the immediacy of sharing thoughts, philosophies and research findings, faculty bloggers Glenn interviewed spoke of the fulfillment of having anyone join in discussions about their postings.

Academic librarians are often in pursuit of equality with their faculty colleagues. The faculty blogoverse is one place where we may be able to establish our presence as partners in higher education. As Glenn noted, "To a remarkable degree, blogs also appear to bring full professors, adjuncts, and students onto a level field." To get on the field we first need to become readers of faculty blogs.

For others, their initial exposure to the world of faculty blogs came courtesy of an essay published in the October 7, 2005, issue of

David Murray is reference librarian for history, e-mail: dcm@temple.edu, and Steven Bell is associate university librarian at Temple University, e-mail: bells@temple. edu

@ 2007 David Murray and Steven Bell 
The Chronicle Review by Henry Farrell. Titled "The blogosphere as a carnival of ideas," this essay introduced many in higher education to the challenges and rewards of blogging as a faculty member. "Why," Farrell asked, "are so many academics beginning to blog?" He wrote that faculty "blogs offer the kind of intellectual excitement and engagement that attracted many scholars to the academic life in the first place, but which often get lost in the hustle to secure positions, grants, and disciplinary recognition." Librarians blog for many of the same reasons that Farrell pointed to for faculty blogs: to have their voices heard, to reach a wider audience, to write interesting daily thoughts, to reconnect with the public, and to debate each other publicly.

\section{Discovering faculty blogs}

Quite a few faculty are blogging. According to research conducted by Thomson Learning about faculty members' openness to using new technology, nearly 10 percent of faculty have their own blogs. By comparison only 8 percent of Americans have a blog. With all these faculty blogs, how should a librarian go about discovering faculty blogs that will be of interest or provide insights into a specific discipline? The readings by Glenn and Farrell serve as a good starting point for academic librarians wishing to explore the "Carnival of ideas." Between the two of them, dozens of faculty blogs are identified, and these lists include some well-known faculty blogs such as Crooked Timber, Balkinization, and The Volokh Conspiracy.

Since the publication of his essay Farrell has developed his own Academic Blog Portal, which lists dozens and dozens of them, organized by discipline. The other primary directory is Blog Scholar. It too refers to itself as the "academic blogging portal." While some unique blogs are found at each site, there are two significant differences. First, the Academic Blog Portal provides a U.S. perspective, while Blog Scholar is U.K.-based. Second, Blog Scholar is also a blog, and provides occasional postings about developments in the world of faculty blogging. The Academic Blog Portal is simply a directory in wiki form. Between the two, academic librarians will have many faculty blogs from which to choose.

Although it is no longer maintained, another good listing of important faculty blogs resides at Rhetorica: Professors Who Blog. Despite being last updated July 2006, many of the blogs listed here are still active. While directories and listings of blogs are good starting points, we have made great discoveries by scanning the blogrolls of our favorite faculty blogs. Following the trails laid by blogrolls is a serendipitous approach that can lead to some exciting finds.

To take this path start at either Crooked Timber or Cliopatria, a group history blog. Each will lead an adventurous academic librarian to dozens more faculty blogs. Another good technique for those who prefer to discover faculty blogs serendipitously is to take a weekly peek at Inside Higher Ed's "Around the Web" page. It features posts from two faculty or academic blogs daily. That's also a good way to keep up with discussions in the faculty blogoverse.

\section{Benefits of reading faculty blogs}

One thing that surprises us is how few academic librarian bloggers ever mention posts written by faculty. It's almost as if an invisible barrier separated our two blogoverses. Yet we have a surprising number of issues in common. It seems we should be crossreferencing posts more frequently. Before that can happen, academic librarians need to start paying more attention to faculty blogs. Here are some reasons why they should:

1. to gain insight into issues of concern to faculty members;

2. to better understand faculty perspectives on issues related to the disciplines and higher education;

3. to improve collection development efforts by identifying new and forthcoming publications of interest to faculty;

4. to identify faculty with similar interests to their own;

5. to learn more about the latest trends in pedagogy as practiced by faculty; 
6. to expose oneself to what faculty will say about students, administrators, and other faculty; and

7. to potentially foster contact with their own faculty.

One way to recognize the benefits of reading faculty blogs is to put them into the context of an issue of interest to both librarians and faculty. Consider social networks as an example. Both of our communities have explored these networks and debated how they can be of use in communicating and virtually connecting with our students. Matthew Williams, a writing instructor at the University of Minnesota, wrote an interesting post about MySpace and Facebook in reaction to a faculty member who criticized social networks for distracting students from more important assignments. Williams also shares his thoughts on the use of technology in the classroom, challenges to good pedagogy, and other topics of interest to those who teach.

Librarians can learn what faculty think about library issues from reading faculty blogs. The Cranky Professor is a somewhat offbeat blog that covers a great deal of academic territory. In between musings on life, the arts, and higher education, the Cranky Professor may also reflect on his experience serving on his institution's library committee. In one post he laments his institution's inability to afford many desired publications, and the challenges the collection development librarian faces in trying to acquire the publications requested by faculty. What this and other faculty blog posts offer for academic librarians are windows into their perspectives and feelings about issues that affect us both.

A faculty blog post can do what a formal curricula vitae or professional Web page cannot. It can reveal a wide range of useful information about a faculty member; information not otherwise easily obtained. Of course blogs by no means substitute for personal communication with the faculty. It isn't necessary to follow dozens of faculty blogs, and indeed there are many from which to choose. To gain efficiency and achieve productivity, a preferred strategy is to focus on those blogs specific to a disciplinary specialty. Here is how that approach can help.

\section{The disciplinary focus}

History as a discipline has benefited from the timely, accessible, and collaborative nature of blogging. Easily Distracted, edwired, and Blog Them Out of the Stone Age are but three of the many notable blogs written by professional

\section{Blogs to visit}

- Academic Blog Portal, wiki.henryfarrell. net/wiki/index.php/Main_Page

- AHA Today, blog.historians.org/

- Around the Web, insidehighered.com /around_the_web

- Balkinization, balkin.blogspot.com/

- BibliOdyssey, bibliodyssey.blogspot. $\mathrm{com} /$

- BlogScholar.com, www.blogscholar. com/component/option,com_frontpage /Itemid,1/

- Blog Them Out Of The Stone Age, warhistorian.org/wordpress/index.php

- Chronicle Daily News, chronicle. com/news/

- Cliopatria, hnn.us/blogs/2. html?id=1829
- Cranky Professor, crankyprofessor.com/

- Crooked Timber, www.crookedtimber. org/

- Easily Distracted, weblogs.swarthmore. edu/burke/

- edwired, edwired.org/

- Frog In A Well, www.froginawell.net/

- Inside Higher Ed, www.insidehighered. com/

- Professor Hidalgo, dennishidalgo. blogspot.com/

- Rhetorica, rhetorica.net/professors _who_blog.htm

- The Volokh Conspiracy, www.volokh. $\mathrm{com} /$

- Wired Campus Blog, chronicle.com /wiredcampus/ 
historians. Prominent group blogs include AHA Today (the official blog of the American Historical Association), Cliopatria, and the beautifully executed Frog in a Well. Blogs written by multiple contributors can be especially active places. Group faculty blogs tend to contain shorter posts than those authored by individuals, but they typically offer more posts overall. The most engaging posts enrich the historical debate by drawing in people ordinarily excluded from such discussions. Interested amateurs, graduate students, and nonhistory faculty have in fact written some of the best posts on historical topics.

What, exactly, can a librarian learn from these disciplinary-focused blogs and perhaps those more generic? The answer to this question depends in part on the librarian's knowledge of the department she or he serves. A librarian who supports a department with a strong military history program, for example, might wish to identify monographs that will attract the attention of faculty members located in the department. In Blog Them Out of the Stone Age, Mark Grimsley, an Ohio State military historian, blogs about his must-have book, Civilians in the Path of War. ${ }^{1}$ And in a guest post on Grimsley's blog, "What Happens When Non-military Historians Teach Military History," historian Rebecca Goetz discusses the sometimes controversial role played by military history within the larger discipline, thereby alerting an observant librarian to potential fault lines between military and social historians in the department.

In his blog Professor Hidalgo, Latin American historian Dennis R. Hidalgo recently wrote about "Wikipedia as a Research Source." That's a topic of obvious interest to academic librarians because we need to know what faculty are telling students about Wikipedia, and the ways in which they are assigning students to use it for research assignments. The visually satisfying BibliOdyssey delights with high-quality historical images. In short, the value to academic librarians of faculty blogs is almost boundless, but rests particularly on two of the pillars of our professional responsibilities: collection development and outreach/liaison responsi- bilities. In both cases reading faculty blogs will strengthen a librarian's ability to perform these duties.

\section{Conclusion}

From the hundreds of faculty blogs available, we believe that academic librarians should be able to identify several that can add an entirely new dimension to personal professional development. Reading faculty blogs provides a unique perspective into the world of higher education and disciplinary specializations. The blogs of our primary academic colleagues also provide a valuable window into their world. All too often academic librarianship is deeply involved in its own little world; call it navel gazing, if you will. But that world is but a single island in the much larger global enterprise of higher education. Despite protests that keeping up already takes too much time, and that what time is available is hardly enough for adequate reading of the library literature, we argue that ignoring faculty blogs is something we do at our own professional risk.

As a profession we often express frustration at our inability to collaborate with faculty. There are all too many observations that academic librarians are second-class citizens in the teaching and learning enterprise on our own campuses. What can we do about this? We have a suggestion. Do more to learn what your faculty are thinking and talking about in their professional world. Become more familiar with the issues they are debating within their disciplines. Begin to recognize who are the thought leaders and visionaries within the professoriate. These activities are valuable, but they will do more than stimulate your passion about the role you play in the higher education industry. They will make you a better colleague with your faculty partners. That is the first step to achieving progress on the path to true collaboration and respect as an educator.

\section{Note}

1. Mark Grimsley and Clifford J. Rogers, Civilians in the Path of War (University of Nebraska Press, 2002). n 